\title{
Molluscum contagiosum: an update and review of new perspectives in etiology, diagnosis, and treatment
}

This article was published in the following Dove Press journal: Clinical, Cosmetic and Investigational Dermatology

\author{
Rodrigo Meza-Romero' \\ Cristián Navarrete- \\ Dechent ${ }^{1,2}$ \\ Camila Downey' \\ 'Department of Dermatology, Facultad \\ de Medicina, Pontificia Universidad \\ Católica de Chile, Santiago, Chile; \\ ${ }^{2}$ Dermatology Service, Memorial Sloan \\ Kettering Cancer Center, New York, \\ NY, USA
}

\begin{abstract}
Molluscum contagiosum (MC) is a self-limited infectious dermatosis, frequent in pediatric population, sexually active adults, and immunocompromised individuals. It is caused by molluscum contagiosum virus (MCV) which is a virus of the Poxviridae family. MCV is transmitted mainly by direct contact with infected skin, which can be sexual, non-sexual, or autoinoculation. Clinically, MC presents as firm rounded papules, pink or skin-colored, with a shiny and umbilicated surface. The duration of the lesions is variable, but in most cases, they are self-limited in a period of 6-9 months. The skin lesions may vary in size, shape, and location, which is more frequent in immunosuppressed patients, and could present complications such as eczema and bacterial superinfection. The diagnosis is based on clinical findings. A useful clinical tool is dermoscopy. If the diagnostic doubt persists, confocal microscopy or skin biopsy could be performed. The need for active treatment for MC is controversial; however, there is a consensus that it should be indicated in cases of extensive disease, associated with complications or aesthetic complaints. There are several treatment modalities which include mechanical, chemical, immunomodulatory, and antivirals. The objective of this article is to review the current evidence in etiology, clinical manifestations, diagnosis, and management alternatives of MC.
\end{abstract}

Keywords: molluscum contagiosum, dermoscopy, confocal microscopy, eczema molluscorum, treatment, molluscum contagiosum virus

\section{Introduction}

Molluscum contagiosum (MC) is a self-limited infectious dermatosis, frequent in the pediatric population, sexually active adults, and immunocompromised individuals. It is transmitted mainly by direct contact with infected skin and clinically is characterized by umbilicated pink or skin-colored papules. ${ }^{1,2}$ It is a frequent reason for consultation in pediatric dermatology and, given its self-limited nature, ${ }^{3}$ the decision to treat or not becomes complex and taken on a case-by-case basis. In this article, we performed an extensive review of the available literature on etiopathogenesis, epidemiology, typical and atypical clinical manifestations, complementary diagnostic tools, and possible treatment alternatives of MC.

\section{Search method}

The relevant literature was found by searching different databases: PubMed, Embase, LILACS, and the Cochrane library. Also, an extensive review of the bibliography of each
Correspondence: Camila Downey Department of Dermatology, Facultad de Medicina, Pontificia Universidad Católica Macul, Santiago, Chile

Tel +5 6223548492

Fax +5625529974

Email camiladowney@gmail.com 
Table I Key literature of this review

\begin{tabular}{|l|l|}
\hline Authors & Title of the article and publication year \\
\hline $\begin{array}{l}\text { Leung et al } \\
\text { Gerlero et } \mathrm{al}^{2} \\
\text { van der Wouden et } \mathrm{al}^{3}\end{array}$ & $\begin{array}{l}\text { Molluscum Contagiosum: An Update. 20I7. } \\
\text { Update on the Treatment of Molluscum Contagiosum in children. 2018. } \\
\text { Interventions for cutaneous Molluscum Contagiosum. 20I7. }\end{array}$ \\
\hline
\end{tabular}

of the inlcuded articles was performed. A summary of the key literature is available in Table 1.

\section{Etiology and epidemiology}

$\mathrm{MC}$ is caused by molluscum contagiosum virus (MCV), a double-strand DNA virus which belongs to the Poxviridae family; humans are MCV only host. MCV has 4 different genotypes: MCV 1, MCV 2, MCV 3, and MCV 4. MCV 1 is the most common genotype (75-96\%), followed by MCV 2, while MCV 3 and 4 are extremely infrequent. ${ }^{1,4,5}$ A Slovenian study ${ }^{4}$ showed that in children MCV 1 infection is more frequent than in adults, and in adult women, MCV 2 infection is more frequent than MCV 1.

MCV infects the epidermis and replicates in the cytoplasm of cells with a variable incubation period between two and six weeks. ${ }^{6}$ Different studies have been developed to sequence the genome of this virus and determine possible genes involved in the evasion of the host immune response, a hypothesis that arose based on the absence of inflammation observed in histopathological samples of infected skin. ${ }^{7,8}$ To date, four viral genes have been identified that code proteins that would alter the activation of the nuclear factor $\mathrm{kB}(\mathrm{NF}-\mathrm{kB})$ : $\mathrm{MC159}, \mathrm{MC160}, \mathrm{MC132}$, and $\mathrm{MC} 005 .^{8-11} \mathrm{NF}-\mathrm{kB}$ is a nuclear protein complex present in dendritic cells that regulate the transcription of DNA and facilitate the synthesis of pro-inflammatory cytokines (TNF, IL-1, IL-6, among others) and activation of innate and acquired immune response. ${ }^{12}$ Brady et $\mathrm{al}^{8,11}$ have seen that $\mathrm{MC} 132$ and $\mathrm{MC} 005$ proteins would alter the activation of NF-kB by inhibiting pattern recognition receptors (PRRs). Added to this, MC132 would bind and stimulate the degradation of the p65 subunit of NF-kB and MC005 would inhibit the activation of the IKK complex (IkB kinase) binding to active NEMO subunit (essential modulator of NF-kB).

$\mathrm{MCV}$ is transmitted by direct contact with infected skin, which can be sexual, non-sexual, or by autoinoculation. Additionally, it can be transmitted by contaminated fomites like bath sponges or towels. ${ }^{1}$ It has been associated with the use of the swimming pool. ${ }^{6}$
MC occurs worldwide and is more frequent in children but can also affect adolescents and adults. It typically affects children between 2-5 years old, being rare under the age of 1 year. There are no gender differences. ${ }^{13}$ Data on the prevalence of $\mathrm{MC}$ is limited. A meta-analysis of cross-sectional surveys among children revealed an overall prevalence of $8.28 \%$ (95\% CI 5.1-11.5) and showed a higher frequency in geographical areas with warm climates. ${ }^{14}$ In the United States, it is estimated that the prevalence in children is less than $5 \%{ }^{15}$

Regarding seroprevalence, the findings are variable in different populations. An Australian study ${ }^{16}$ using enzymelinked immunosorbent assay (ELISA) revealed an overall seropositivity rate for MCV of $23 \%$ in children and adults. Sherwani et $\mathrm{al}^{17}$ found a seroprevalence of $14.8 \%$ in German children and adults between 0 and 40 years, and 30.3\% in a population of 30 healthy individuals from the United Kingdom with a mean age of 27 years; in both studies, seroprevalence was determined by ELISA of antibodies against MC084 protein. Watanabe et $\mathrm{al}^{18}$ found a seroprevalence of $6 \%$ in a healthy Japanese population, determined by ELISA of antibodies against an N-terminal truncation of MC133 protein.

In adolescents and adults, MC could occur either as a sexually transmitted disease or in relation to contact sports. ${ }^{19}$ It is more common in immunosuppressed patients: In the 1980s, the number of reported cases of MC increased, apparently associated with the onset of the acquired immune deficiency virus (HIV) epidemic. ${ }^{20}$ It is estimated that in HIV patients the prevalence is close to $20 \% .^{21}$ Besides HIV, MC may be associated with iatrogenic immunosuppression or primary immunodeficiencies (eg, DOCK8 immunodeficiency syndrome). ${ }^{22}$

Atopic dermatitis (AD) has been proposed as a risk factor for MC. However, studies on this subject are controversial. Some studies have found an increased risk of $\mathrm{MC}$ in patients with $\mathrm{AD},{ }^{23,24}$ with prevalence rates of $\mathrm{AD}$ in patients with $\mathrm{MC}$ of up to $62 \% .{ }^{6,25}$ It has even been postulated an increased risk of MCV infection in patients with $\mathrm{AD}$ and filaggrin mutation. ${ }^{26}$ Other studies have shown no significant differences. ${ }^{27}$ 


\section{Clinical manifestations}

Patients infected with MCV present firm rounded papules from 2 to $5 \mathrm{~mm}$, pink or skin-colored, with a shiny and umbilicated surface (Figure 1). The lesions may be single, multiple or clustered, and occasionally they may have an erythematous halo or be pediculated. Pruritus may be present.

In children, the main affected areas are sites of exposed skin, such as the trunk, extremities, intertriginous regions, genitals, and face, except the palms and soles. ${ }^{28}$ The involvement of the oral mucosa is rare. ${ }^{29}$ In adults, lesions are most frequently located in the lower abdomen, thighs, genitals, and perianal area, most of the cases transmitted by sexual contact. In children, genital lesions are mainly due to autoinoculation and are not pathognomonic of sexual abuse. ${ }^{30}$

The duration of the lesions is variable, but in most cases, they are self-limiting in a period of 6 to 9 months; however, some cases may persist for more than 3 or 4 years. ${ }^{3}$ It has described a phenomenon called "beginning of the end" (BOTE) sign which refers to clinical erythema and swelling of an $\mathrm{MC}$ skin lesion when the regression phase begins (Figure 2). This phenomenon is likely due to an immune response towards the $\mathrm{MC}$ infection rather than a bacterial superinfection. ${ }^{1,25,31}$

In immunosuppressed patients, such as those infected with HIV, lesions may be extensive, located in atypical sites, greater than $1 \mathrm{~cm}$ in diameter (giant $\mathrm{MC}$ ) or refractory to treatment. ${ }^{32-34}$

Patients may develop eczematous plaques around one or more lesions of MC, a phenomenon known as "molluscum dermatitis" (MD) or "eczema molluscorum" (EM) which is more frequent in patients with $\mathrm{AD}$. It is estimated that $9-47 \%$ of the patients with MC develop MD. ${ }^{25}$ It is

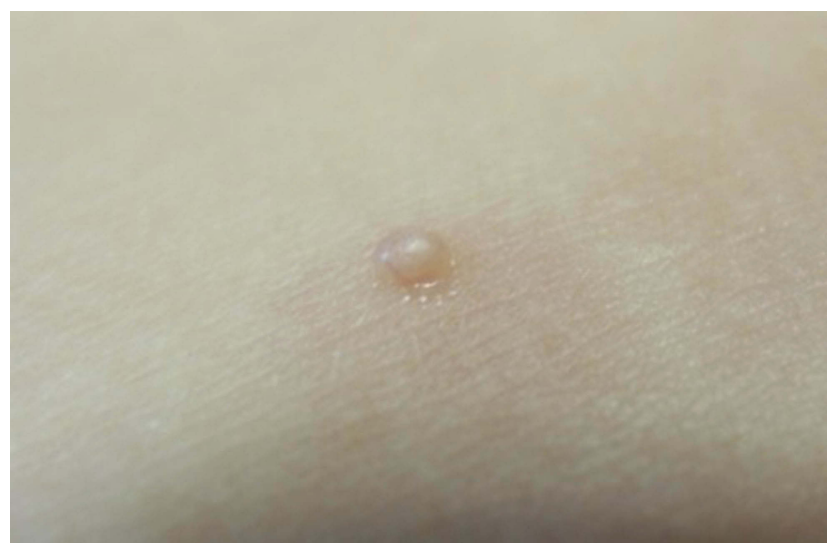

Figure I Firm, rounded, skin-colored papules with a shiny and umbilicated surface.

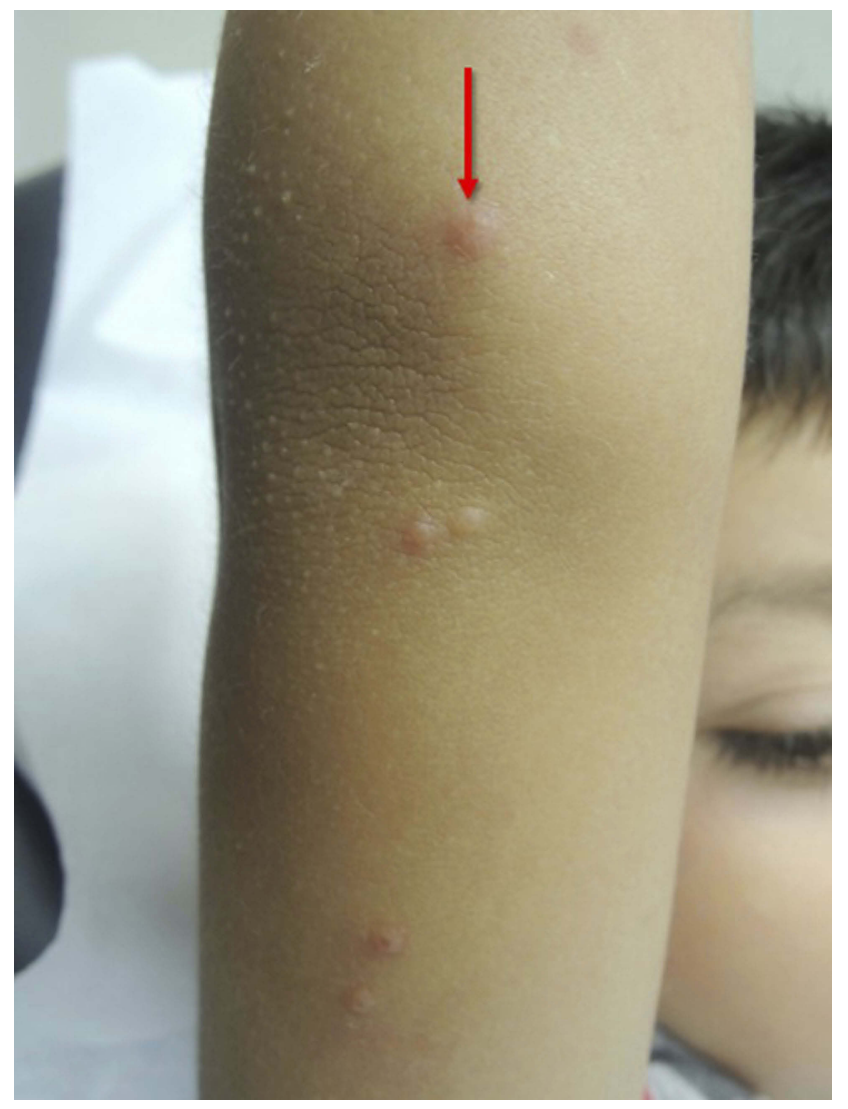

Figure 2 Swelling and erythema of the "BOTE" sign.

not clear whether the treatment of MD with topical corticosteroids impacts the resolution of $\mathrm{MC}$ lesions. ${ }^{35,36}$

MC lesions can also be congenital when transmitted vertically by contact with MCV in the birth canal. ${ }^{37,38}$ In this case, lesions are typically located on the scalp and have a circular arrangement. ${ }^{38}$ Other sites of atypical location, ${ }^{1}$ in addition to the oral mucosa, include the palms and soles, the areola/nipple, ${ }^{39,40}$ the conjunctiva, ${ }^{41}$ lips ${ }^{42}$ eyelids, ${ }^{43}$ among others. ${ }^{44}$ Clinical presentation of periocular lesions has been described as erythematous, nodular umbilicated, big/giant, conglomerated, inflamed, or pedunculated. ${ }^{45}$ The periocular presentation has also been associated with conjunctivitis. ${ }^{46}$

\section{Diagnosis}

The diagnosis of MC is clinically based on the distinguishing characteristics of the lesions. A useful clinical tool in the diagnosis of $\mathrm{MC}$ is dermoscopy, ${ }^{1}$ which is a widely available tool that enables to observe structures not seen by the naked eye with a 10X magnification. MC display characteristic findings under the dermatoscope: a central pore or umbilication, polylobular white-to-yellow amorphous structures, and 


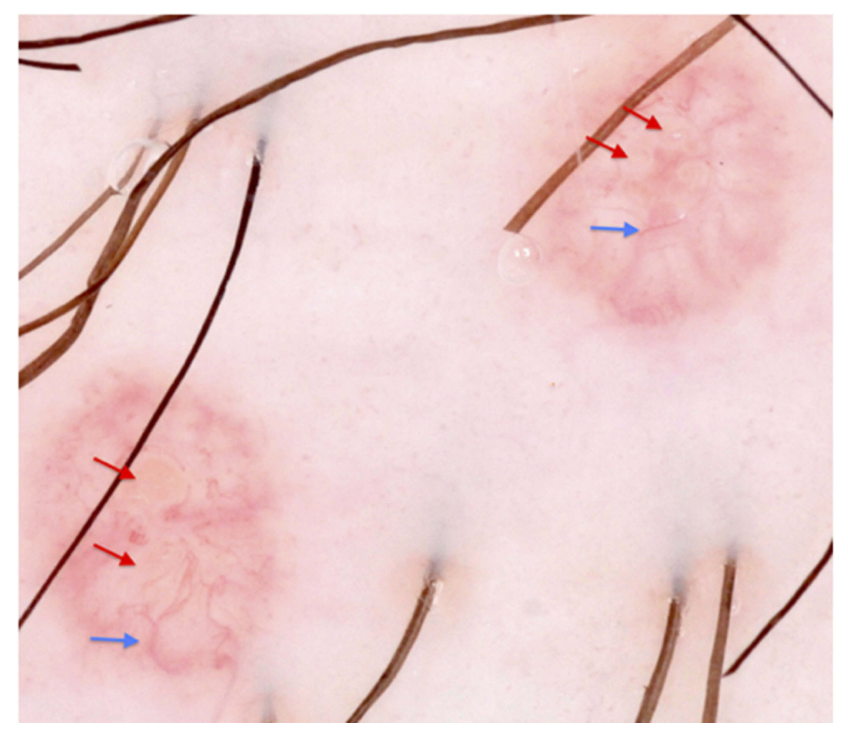

Figure 3 Dermatoscopic findings of MC. Red arrows: white-to-yellow polylobular structures. Blue arrows: crown vessels. (Polarized-light dermoscopy, original magnification 10x).

peripheral crown vessels (Figure 3). ${ }^{47-49}$ They can also have rosettes when seen under polarized light. Diagnosis is usually straightforward when typical MC findings are seen; however, some irritated or excoriated cases of MC may be indistinguishable from other tumors. ${ }^{50}$ Other emerging diagnostic modalities that may aid in the diagnosis of $\mathrm{MC}$ include reflectance confocal microscopy (RCM). Under RCM they appear as round, well-circumscribed lesions, with central round-to-cystic areas filled with bright refractile material. ${ }^{51,52}$

The histopathological study is indicated when the diagnosis is not clear (see differential diagnosis below). The characteristic findings correspond to large intracytoplasmic eosinophil inclusion bodies known as HendersonPetterson bodies (Figure 4). ${ }^{30}$

The differential diagnoses include mainly inflammatory, infectious, and neoplastic etiologies; they mainly differ according to the age and immunologic status of the patient (Table 2). ${ }^{1}$ In immunosuppressed patients, the main differential diagnosis includes histoplasmosis and cryptococcosis which can be seen as umbilicated papules. ${ }^{53}$

\section{Treatment}

Currently, the need for active treatment in patients with MC is controversial, given the self-limited course of infection, the large number of therapeutic alternatives available, and the lack of evidence to define the best therapy. There is a consensus that treatment should be indicated in patients with extensive disease, secondary complications (bacterial superinfection, molluscum dermatitis, conjunctivitis), or

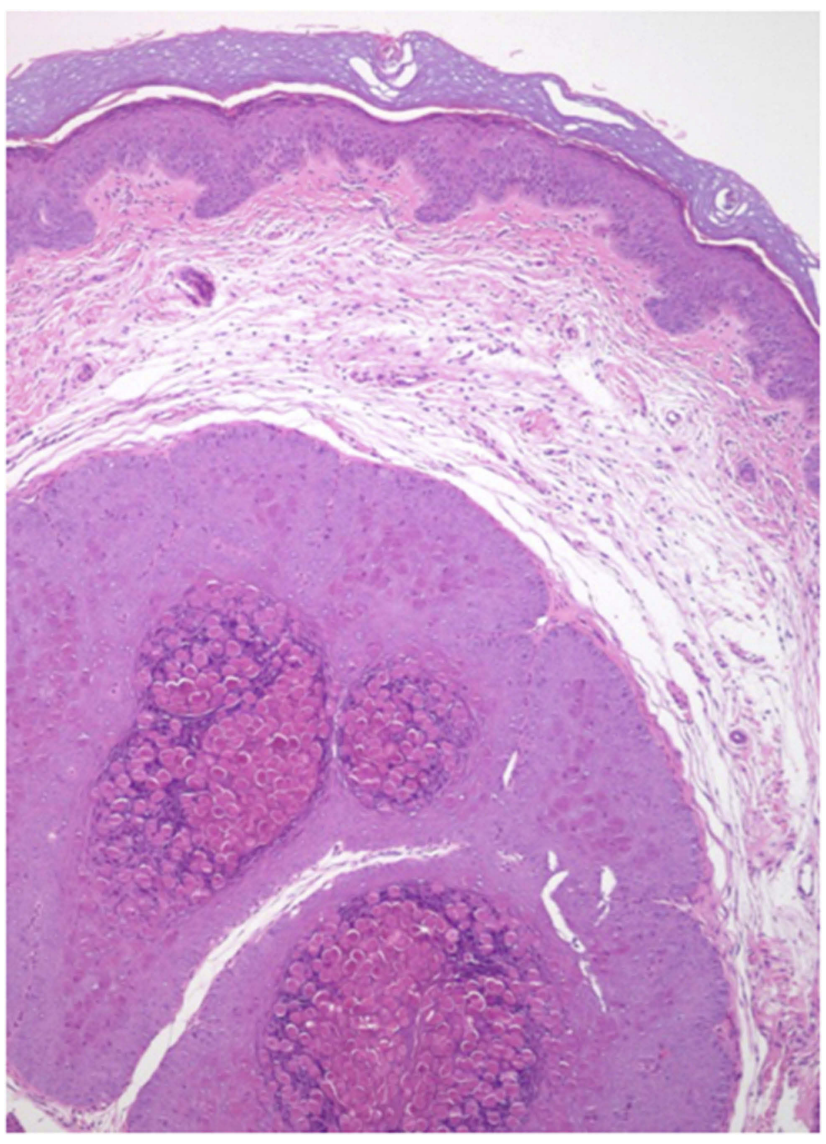

Figure 4 Large intracytoplasmic eosinophil inclusion bodies called HendersonPetterson bodies. This photo was provided courtesy of Alejandra Villarroel-Pérez, MD. H\&E, I0× magnification.

Table 2 Molluscum contagiosum differential diagnosis

\begin{tabular}{|c|c|}
\hline Infections & $\begin{array}{l}\text { Verruca vulgaris }^{88} \\
\text { Chickenpox }^{89} \\
\text { Folliculitis' } \\
\text { Condyloma acuminatum' }\end{array}$ \\
\hline Tumors & $\begin{array}{l}\text { Syringomas }^{90} \\
\text { Steatocystoma multiplex } \\
\text { Basal cell carcinoma }^{11}\end{array}$ \\
\hline Miscellaneous & $\begin{array}{l}\text { Acne vulgaris } \\
{ }^{92} \\
\text { Gianotti-Crosti Syndrome } \\
\text { Milia' }^{25} \\
\text { Sebaceous hyperplasia }^{93} \\
\text { Papular urticaria' }\end{array}$ \\
\hline
\end{tabular}

aesthetic complaints. ${ }^{1}$ A retrospective study $^{54}$ evaluated the resolution rate of the lesions in treated and untreated $\mathrm{MC}$ patients, showing a resolution at 12 months of $45.6 \%$ in the treated group and $48.8 \%$ in the untreated group. At 18 months, they found a resolution rate of $69.5 \%$ and $72.6 \%$ in the treated versus the untreated group, respectively. From 
this cardinal study, it appears that active treatment does not improve the resolution rate when compared to observation alone.

For all patients, general measures are recommended to prevent the spread of MCV. ${ }^{1-3}$ It should be advised not to scratch or rub the lesions; besides, patients should not share towels, tub, or bath utensils.

Active treatments can be classified as ${ }^{1}$ mechanical, chemical, immunomodulatory, and antiviral.

\section{Mechanical methods}

Cryotherapy is an effective treatment. It can be applied with a cotton-tipped swab or by portable sprayers, 1 or 2 cycles of 10 to 20 seconds are typically used. ${ }^{2}$ A prospective, randomized and comparative trial $^{55}$ evaluated the efficacy of cryotherapy in MC treatment. The study demonstrated a complete clearance in $70.7 \%$ of the patients at 3 weeks and in $100 \%$ of them at 16 weeks. Another study ${ }^{56}$ showed full clearance in $83.3 \%$ of 60 patients (average age of 20 years) at 6 weeks. In both, the application of cryotherapy was administered weekly. The disadvantages of cryotherapy are the possibility of blistering, scarring, and post-inflammatory hypo or hyperpigmentation. $^{2}$

Curettage is also an effective method and involves the physical removal of skin lesions. ${ }^{2}$ One study showed that of 1,879 children, $70 \%$ were cured with one session while $26 \%$ needed two sessions, with overall satisfaction of $97 \%$ in both parents and children. ${ }^{57}$ A randomized, controlled trial $^{58}$ showed a complete clearance with only one curettage session in $80.3 \%$ of the patients and without recurrences at 6 months of follow-up. It can be done with a curette, punch biopsy (Figure 5) or with an ear speculum. ${ }^{59,60}$ To reduce pain, topical application of EMLA (eutectic mixture of local anesthetics), a combination of $2.5 \%$ lidocaine and $2.5 \%$ prilocaine, may be required $1 \mathrm{hr}$ before the procedure. ${ }^{57,61}$ Curettage can cause pain, bleeding, and scarring.

After curettage, topical povidone iodine can be applied. This is an antiseptic useful in the treatment of MC based on case reports ${ }^{62}$ and our experience. A systematic review of 2017 showed that povidone-iodine $10 \%$ potentiates the effect of $50 \%$ salicylic acid, without adverse effects reported. ${ }^{3}$ For topical povidone iodine, we propose an application scheme of 3 times a day until the resolution of the cutaneous lesions. We use it routinely after use of other treatment modalities.

Another useful mechanical method is pulse dye laser therapy, which due to its costs and limited availability is suggested to be left for refractory cases. ${ }^{1,63}$ It is an

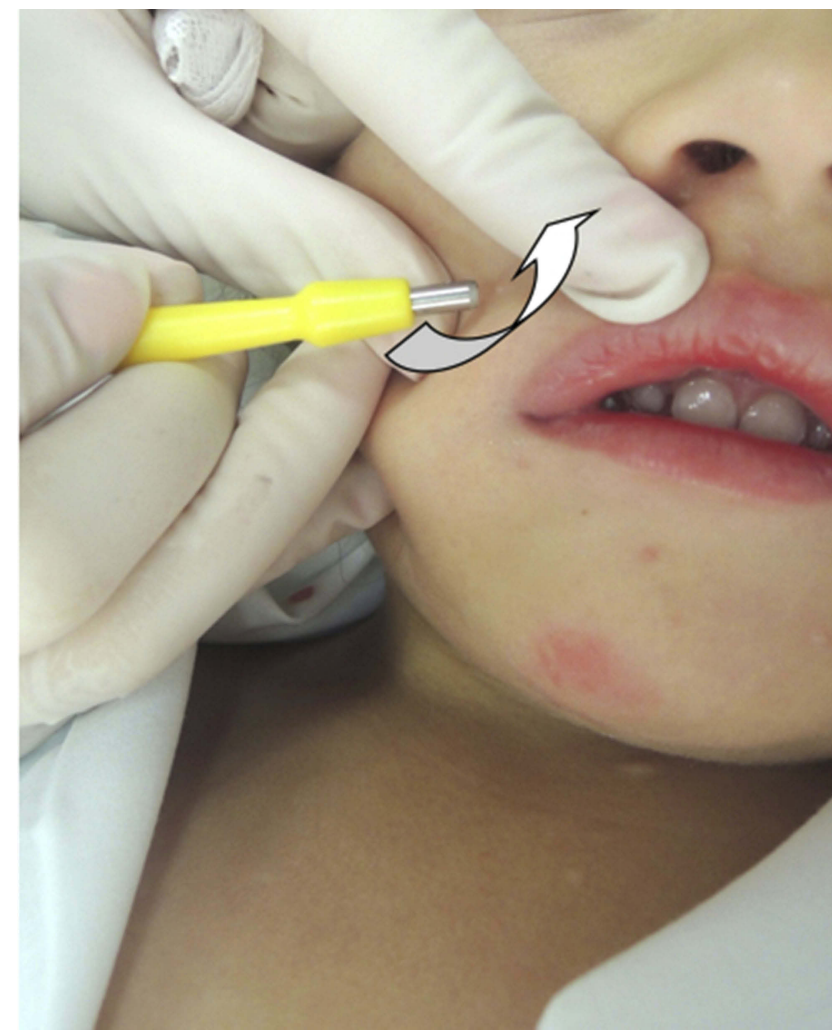

Figure 5 Mechanical removal (curettage) of a molluscum contagiosum with a punch tool. The punch should be positioned in $<30^{\circ}$ to the skin surface and a shear movement should be performed to remove the molluscum in its entirety.

effective, safe, and well-tolerated treatment, with infrequent adverse effects. ${ }^{63}$ Cases of successful use in immunosuppressed patients have also been reported. ${ }^{64}$

\section{Chemical methods}

Chemical methods destroy skin lesions through the inflammatory response they produce. Cantharidin is a topical agent, an inhibitor of phosphodiesterase, which produces an intraepidermal blister, followed by resolution of the lesion and healing without a scar in some cases. ${ }^{65}$ The efficacy of cantharidin in the treatment of $\mathrm{MC}$ is variable, with cure rates varying between $15.4 \%$ and $100 \%$ among the different studies. ${ }^{66,67}$ It is recommended to apply cantharidin $0.7-0.9 \%$ at the site of the lesion, with or without occlusion, and to wash with soap and water 2-4 hrs later, each every 2-4 weeks until the resolution of lesions. $^{2,58,65}$ In the face and anogenital region it should be used with precaution due to the risk of bacterial superinfection of blisters that form after $24-48 \mathrm{hrs}^{2,68}$

Potassium hydroxide is an alkaline compound that dissolves keratin. ${ }^{2}$ It has been used in concentrations and therapeutic schemes that vary from $5 \%$ to $20 \%$, two times a day or every other day for 1 week or until inflammation develops. ${ }^{69}$ 
A recent study ${ }^{70}$ showed that $10 \%$ and $15 \%$ potassium hydroxide clear lesions of MC entirely in $58.8 \%$ and $64.3 \%$ of the patients, respectively. It would be a safe and effective treatment that could be applied by patients, and its effectiveness has been compared with cryotherapy and imiquimod without significant differences. ${ }^{69,71}$

Other chemical methods reported are: podophyllotoxin, trichloroacetic acid, salicylic acid, lactic acid, glycolic acid, benzoyl peroxide, and tretinoin. ${ }^{1,2,62}$

\section{Immunomodulatory methods}

Immunomodulatory methods stimulate the patient's immune response against the infection. Imiquimod is an immunestimulatory agent agonist of the toll-like receptor 7 that activates the innate and acquired immune response. ${ }^{2}$ It is a useful alternative in the treatment of MC based on case reports and uncontrolled studies. ${ }^{31,72}$ A prospective, randomized trial ${ }^{55}$ compared the efficacy of cryotherapy with 5\% imiquimod, demonstrating a complete clearance in $100 \%$ of the patients at 16 weeks for cryotherapy versus $92 \%$ for imiquimod $5 \%$ (difference not statistically significant). Cutaneous adverse effects were more frequent in the cryotherapy group. However, a recent systematic review showed that it is not better than placebo in short-term improvement ( 3 months) or long-term cure (more than 6 months) and may produce adverse effects at the application site such as pain, blistering, scars and/or pigmentary changes. ${ }^{3}$ The current evidence positions imiquimod as a controversial therapeutic alternative. ${ }^{73}$

Other immunomodulatory methods are oral cimetidine, interferon alfa, candidin, and diphencyprone.

Oral cimetidine is an $\mathrm{H} 2$ receptor antagonist that would stimulate the delayed hypersensitivity response. ${ }^{2}$ It is a safe and well-tolerated drug, and the recommended dose is $25-40 \mathrm{mg} / \mathrm{kg} /$ day. It would be more effective in non-facial lesions. ${ }^{1}$

Interferon alfa is a proinflammatory cytokine that is used in the treatment of MC in immunosuppressed patients with severe or refractory disease. It can be administered subcutaneously or intralesionally. ${ }^{74-76}$

Candidin is intralesional immunotherapy derived from the purified extract of Candida albicans. It is an alternative in the treatment of $\mathrm{MC}$, being applied purely or diluted at $50 \%$ with lidocaine in a dose of $0.2-0.3 \mathrm{~mL}$ intralesional every 3 weeks. ${ }^{2}$ A retrospective study evaluating the efficacy of candidin in the treatment of MC showed a complete resolution rate of $55 \%$ and a partial resolution of $37.9 \%$, with an overall response rate of $93 \%{ }^{77}$
Diphencyprone is a topical immunomodulator used in multiple skin diseases. Cases of successful treatment with diphencyprone have been reported in immunosuppressed and immunocompetent patients. ${ }^{78,79}$

\section{Antivirals}

Another method used in immunosuppressed patients with extensive or refractory disease is cidofovir, an antiviral drug initially used in cytomegalovirus retinitis in HIV patients. It can be used topically at a concentration of $1-3 \%$ or intravenously. ${ }^{80-82}$ The major problem with intravenous administration is nephrotoxicity. ${ }^{83}$

\section{New therapies}

New MC treatments include topical sinecatechins, ${ }^{84}$ intralesional 5-fluorouracil, ${ }^{85}$ hyperthermia, ${ }^{86}$ and zoster immune globulin. ${ }^{87}$ Evidence is preliminary to determine the effectiveness of these therapies.

\section{Conclusion}

$\mathrm{MC}$ is a frequent reason for consultation in dermatology and the decision to treat or not should be considered for each patient, taking into account its self-limited course and benign nature. There are multiple treatment alternatives with variable efficacy; risks and benefits should be balanced and discussed on a patient-by-patient basis. From our point of view, and based on the available evidence, it appears that curettage with or without topical anesthesia, or the application of $0.7 \%$ cantharidin, are the most cost-effective alternatives. Currently, a series of investigations are being carried out to determine the effectiveness of the available treatments and find new therapeutic options.

\section{Ethical concerns}

The figures presented in this article were taken from patients in our center, not from books or other articles, and the parents authorized their publication in all cases.

\section{Acknowledgment}

We would want to thank Alejandra Villarroel-Pérez, MD, for her collaboration with histopathological images of MC.

\section{Disclosure}

The authors do not have any conflicts of interest to declare in this work. 


\section{References}

1. Leung AKC, Barankin B, Hon KLE. Molluscum contagiosum: an update. Recent Pat Inflamm Allergy Drug Discov. 2017;11(1):22-31. doi:10.2174/1872213X11666170518114456

2. Gerlero P, Hernandez-Martin A. Update on the treatment of molluscum contagiosum in children. Actas Dermosifiliogr. 2018;109 (5):408-415. doi:10.1016/j.ad.2018.01.007

3. van der Wouden JC, Menke J, Gajadin S, et al. Interventions for cutaneous molluscum contagiosum. Cochrane Database Syst Rev. 2017;5:CD004767.

4. Trcko K, Hosnjak L, Kusar B, et al. Clinical, histopathological, and virological evaluation of 203 patients with a clinical diagnosis of molluscum contagiosum. Open Forum Infect Dis. 2018;5(11):ofy298. doi:10.1093/ofid/ofy298

5. Chen X, Anstey AV, Bugert JJ. Molluscum contagiosum virus infection. Lancet Infect Dis. 2013;13(10):877-888. doi:10.1016/ S1473-3099(13)70109-9

6. Braue A, Ross G, Varigos G, Kelly H. Epidemiology and impact of childhood molluscum contagiosum: a case series and critical review of the literature. Pediatr Dermatol. 2005;22(4):287-294. doi:10.1111/ j.1525-1470.2005.22401.x

7. Zorec TM, Kutnjak D, Hosnjak L, et al. New Insights into the evolutionary and genomic landscape of Molluscum Contagiosum Virus (MCV) based on nine MCV1 and six MCV2 complete genome sequences. Viruses. 2018;10(11). doi:10.3390/v10110586.

8. Brady G, Haas DA, Farrell PJ, Pichlmair A, Bowie AG. Molluscum contagiosum virus protein MC005 inhibits NF-kappaB activation by targeting NEMO-regulated IkappaB kinase activation. $J$ Virol. 2017;91(15). doi:10.1128/JVI.00955-17

9. Shisler JL. Immune evasion strategies of molluscum contagiosum virus. Adv Virus Res. 2015;92:201-252. doi:10.1016/bs.aivir.2014.11.004

10. Biswas S, Smith GL, Roy EJ, Ward B, Shisler JL. A comparison of the effect of molluscum contagiosum virus MC159 and MC160 proteins on vaccinia virus virulence in intranasal and intradermal infection routes. J Gen Virol. 2018;99(2):246-252. doi:10.1099/ jgv.0.001006

11. Brady G, Haas DA, Farrell PJ, Pichlmair A, Bowie AG. Poxvirus protein $\mathrm{MC132}$ from molluscum contagiosum virus inhibits NF-B activation by targeting p65 for degradation. J Virol. 2015;89 (16):8406-8415. doi:10.1128/JVI.00799-15

12. Gurtler C, Bowie AG. Innate immune detection of microbial nucleic acids. Trends Microbiol. 2013;21(8):413-420. doi:10.1016/j.tim.2013.04.004

13. Rogers M, Barnetson RSC. Diseases of the skin. In: Campbell AGM, McIntosh N, et al. editor(s). Forfar and Arneil's Textbook of Pediatrics. 5th Edition. New York: Churchill Livingstone, 1998:1633-5.

14. Olsen JR, Gallacher J, Piguet V, Francis NA. Epidemiology of molluscum contagiosum in children: a systematic review. Fam Pract. 2014;31(2):130-136. doi:10.1093/fampra/cmt075

15. Dohil MA, Lin P, Lee J, Lucky AW, Paller AS, Eichenfield LF. The epidemiology of molluscum contagiosum in children. $J$ Am Acad Dermatol. 2006;54(1):47-54. doi:10.1016/j.jaad.2005.08.035

16. Konya J, Thompson $\mathrm{CH}$. Molluscum contagiosum virus: antibody responses in persons with clinical lesions and seroepidemiology in a representative Australian population. J Infect Dis. 1999;179 (3):701-704. doi:10.1086/314620

17. Sherwani S, Farleigh L, Agarwal N, et al. Seroprevalence of Molluscum contagiosum virus in German and UK populations. PLoS One. 2014;9(2):e88734. doi:10.1371/journal.pone.0088734

18. Watanabe T, Nakamura K, Wakugawa M, et al. Antibodies to molluscum contagiosum virus in the general population and susceptible patients. Arch Dermatol. 2000;136(12):1518-1522.

19. Peterson AR, Nash E, Anderson BJ. Infectious disease in contact sports. Sports Health. 2019;11(1):47-58. doi:10.1177/1941738118789954
20. Koopman RJ, van Merrienboer FC, Vreden SG, Dolmans WM. Molluscum contagiosum; a marker for advanced HIV infection. $\mathrm{Br}$ J Dermatol. 1992;126(5):528-529.

21. Czelusta A, Yen-Moore A, Van der Straten M, Carrasco D, Tyring SK. An overview of sexually transmitted diseases. Part III. Sexually transmitted diseases in HIV-infected patients. $J$ Am Acad Dermatol. 2000;43(3):409-432; quiz 33-6. DOI:10.1067/mjd.2000.105158

22. Kaufman WS, Ahn CS, Huang WW. Molluscum contagiosum in immunocompromised patients: AIDS presenting as molluscum contagiosum in a patient with psoriasis on biologic therapy. Cutis. 2018;101(2):136-140.

23. Olsen JR, Piguet V, Gallacher J, Francis NA. Molluscum contagiosum and associations with atopic eczema in children: a retrospective longitudinal study in primary care. Br J Gen Pract. 2016;66(642): e53-e58. doi:10.3399/bjgp15X688093

24. Silverberg NB. Molluscum contagiosum virus infection can trigger atopic dermatitis disease onset or flare. Cutis. 2018;102(3):191-194.

25. Berger EM, Orlow SJ, Patel RR, Schaffer JV. Experience with molluscum contagiosum and associated inflammatory reactions in a pediatric dermatology practice: the bump that rashes. Arch Dermatol. 2012;148 (11):1257-1264. doi:10.1001/archdermatol.2012.2414

26. Manti S, Amorini M, Cuppari C, et al. Filaggrin mutations and Molluscum contagiosum skin infection in patients with atopic dermatitis. Ann Allergy Asthma Immunol. 2017;119(5):446-451. doi:10.1016/j.anai.2017.07.019

27. Hayashida S, Furusho N, Uchi H, et al. Are lifetime prevalence of impetigo, molluscum and herpes infection really increased in children having atopic dermatitis? J Dermatol Sci. 2010;60(3):173-178. doi:10.1016/j.jdermsci.2010.09.003

28. Schaffer JV, Berger EM. Molluscum contagiosum. JAMA Dermatol. 2016;152(9):1072. doi:10.1001/jamadermatol.2016.2344

29. Fornatora ML, Reich RF, Gray RG, Freedman PD. Intraoral molluscum contagiosum: a report of a case and a review of the literature. Oral Surg Oral Med Oral Pathol Oral Radiol Endod. 2001;92 (3):318-320. doi:10.1067/moe.2001.117299

30. Brown J, Janniger CK, Schwartz RA, Silverberg NB. Childhood molluscum contagiosum. Int J Dermatol. 2006;45(2):93-99.

31. Butala N, Siegfried E, Weissler A. Molluscum BOTE sign: a predictor of imminent resolution. Pediatrics. 2013;131(5):e1650e1653. doi:10.1542/peds.2012-2933

32. Basu S, Kumar A. Giant molluscum contagiosum - a clue to the diagnosis of human immunodeficiency virus infection. $J$ Epidemiol Glob Health. 2013;3(4):289-291. doi:10.1016/j.jegh.2013.06.002

33. Vora RV, Pilani AP, Kota RK. Extensive giant molluscum contagiosum in a HIV positive patient. J Clin Diagn Res. 2015;9(11):Wd01wd02. doi:10.7860/JCDR/2015/15107.6797

34. Husak R, Garbe C, Orfanos CE. [Mollusca contagiosa in HIV infection. Clinical manifestation, relation to immune status and prognostic value in 39 patients]. Hautarzt. 1997;48(2):103-109. doi:10.1007/ s001050050554

35. Osio A, Deslandes E, Saada V, Morel P, Guibal F. Clinical characteristics of molluscum contagiosum in children in a private dermatology practice in the greater Paris area, France: a prospective study in 661 patients. Dermatology. 2011;222(4):314-320. doi:10.1159/000327888

36. Netchiporouk E, Cohen BA. Recognizing and managing eczematous id reactions to molluscum contagiosum virus in children. Pediatrics. 2012;129(4):e1072-e1075. doi:10.1542/peds.2011-1054

37. Berbegal-DeGracia L, Betlloch-Mas I, DeLeon-Marrero FJ, Martinez-Miravete MT, Miralles-Botella J. Neonatal Molluscum contagiosum: five new cases and a literature review. Australas $J$ Dermatol. 2015;56(2):e35-e38. doi:10.1111/ajd.12127

38. Mira-Perceval Juan G, Alcala Minagorre PJ, Betlloch Mas I, Sanchez Bautista A. [Molluscum contagiosum due to vertical transmission]. An Esp Pediatr. 2017;86(5):292-293. doi:10.1016/j.anpedi.2015.12.014

39. Hoyt BS, Tschen JA, Cohen PR. Molluscum contagiosum of the areola and nipple: case report and literature review. Dermatol Online J. 2013;19(7):18965. 
40. Ives C, Green M, Wright T. Molluscum contagiosum: a rare nipple lesion. Breast J. 2017;23(1):107-108. doi:10.1111/tbj.12693

41. Ringeisen AL, Raven ML, Barney NP. Bulbar conjunctival molluscum contagiosum. Ophthalmology. 2016;123(2):294. doi:10.1016/j. ophtha.2015.11.022

42. Ma H, Yang H, Zhou Y, Jiang L. Molluscum contagiosum on the lip. J Craniofac Surg. 2015;26(7):e681-e682. doi:10.1097/ SCS.0000000000002187

43. Serin S, Bozkurt Oflaz A, Karabagli P, Gedik S, Bozkurt B. Eyelid molluscum contagiosum lesions in two patients with unilateral chronic conjunctivitis. Turk Oftalmol Derg. 2017;47(4):226-230. doi:10.4274/tjo.52138

44. Kim HK, Jang WS, Kim BJ, Kim MN. Rare manifestation of giant molluscum contagiosum on the scalp in old age. Ann Dermatol. 2013;25(1):109-110. doi:10.5021/ad.2013.25.1.109

45. Rosner M, Zloto O. Periocular molluscum contagiosum: six different clinical presentations. Acta Ophthalmol (Copenh). 2018;96(5):e600e5. doi:10.1111/aos.13717

46. Schornack MM, Siemsen DW, Bradley EA, Salomao DR, Lee HB. Ocular manifestations of molluscum contagiosum. Clin Exp Optom. 2006;89(6):390-393. doi:10.1111/cxo.2006.89.issue-6

47. Morales A, Puig S, Malvehy J, Zaballos P. Dermoscopy of molluscum contagiosum. Arch Dermatol. 2005;141(12):1644. doi:10.1001/ archderm.141.12.1644

48. Zaballos P, Ara M, Puig S, Malvehy J. Dermoscopy of molluscum contagiosum: a useful tool for clinical diagnosis in adulthood. $J$ Eur Acad Dermatol Venereol. 2006;20(4):482-483. doi:10.1111/j.14683083.2006.01480.x

49. Ianhez M, Cestari Sda C, Enokihara MY, Seize MB. Dermoscopic patterns of molluscum contagiosum: a study of 211 lesions confirmed by histopathology. An Bras Dermatol. 2011;86(1):74-79.

50. Navarrete-Dechent C, Uribe P, Gonzalez S. Desmoplastic trichilemmoma dermoscopically mimicking molluscum contagiosum. J Am Acad Dermatol. 2017;76(2s1):S22-S24. doi:10.1016/j.jaad.2016.04.044

51. Lacarrubba F, Verzi AE, Ardigo M, Micali G. Handheld reflectance confocal microscopy for the diagnosis of molluscum contagiosum: histopathology and dermoscopy correlation. Australas J Dermatol. 2017;58(3):e123-e125. doi:10.1111/ajd.12511

52. Scope A, Benvenuto-Andrade C, Gill M, Ardigo M, Gonzalez S, Marghoob AA. Reflectance confocal microscopy of molluscum contagiosum. Arch Dermatol. 2008;144(1):134. doi:10.1001/ archderm.144.1.134

53. Blanco P, Viallard JF, Beylot-Barry M, et al. Cutaneous cryptococcosis resembling molluscum contagiosum in a patient with nonHodgkin's lymphoma. Clin Infect Dis. 1999;29(3):683-684.

54. Basdag H, Rainer BM, Cohen BA. Molluscum contagiosum: to treat or not to treat? Experience with 170 children in an outpatient clinic setting in the northeastern United States. Pediatr Dermatol. 2015;32 (3):353-357. doi:10.1111/pde.12504

55. Al-Mutairi N, Al-Doukhi A, Al-Farag S, Al-Haddad A. Comparative study on the efficacy, safety, and acceptability of imiquimod $5 \%$ cream versus cryotherapy for molluscum contagiosum in children. Pediatr Dermatol. 2010;27(4):388-394. doi:10.1111/j.1525-1470.2009.00974.x

56. Qureshi A, Zeb M, Jalal-Ud-Din M, Sheikh ZI, Alam MA, Anwar SA. Comparison of efficacy of $10 \%$ potassium hydroxide solution versus cryotherapy in treatment of molluscum contagiosum. J Ayub Med Coll Abbottabad. 2016;28(2):382-385.

57. Harel A, Kutz AM, Hadj-Rabia S, Mashiah J. To treat molluscum contagiosum or not-curettage: an effective, well-accepted treatment modality. Pediatr Dermatol. 2016;33(6):640-645. doi:10.1111/ pde. 12968

58. Hanna D, Hatami A, Powell J, et al. A prospective randomized trial comparing the efficacy and adverse effects of four recognized treatments of molluscum contagiosum in children. Pediatr Dermatol. 2006;23(6):574-579. doi:10.1111/j.1525-1470.2006.00313.x
59. Kelly V, Coulombe J, Lavoie I. Use of a disposable ear speculum: an alternative technique for molluscum contagiosum curettage. Pediatr Dermatol. 2018;35(3):418-419. doi:10.1111/pde.13453

60. Navarrete-Dechent C-M-M, Droppelmann N, González S. Actualización en el uso de la biopsia de piel por punch. Revista Chilena De Cirugía. 2016;68:467-473. doi:10.1016/j.rchic.2016.05.008

61. Gobbato AA, Babadopulos T, Gobbato CA, Moreno RA, Gagliano-Juca T, De Nucci G. Tolerability of 2.5\% lidocaine/ prilocaine hydrogel in children undergoing cryotherapy for molluscum contagiosum. Pediatr Dermatol. 2016;33(3):e214-e215. doi: $10.1111 /$ pde. 12842

62. Capriotti K, Stewart K, Pelletier J, Capriotti J. Molluscum contagiosum treated with dilute povidone-iodine: a series of cases. $J$ Clin Aesthet Dermatol. 2017;10(3):41-45.

63. Griffith RD, Yazdani Abyaneh MA, Falto-Aizpurua L, Nouri K. Pulsed dye laser therapy for molluscum contagiosum: a systematic review. J Drugs Dermatol. 2014;13(11):1349-1352.

64. Fisher C, McLawhorn JM, Adotama P, Stasko T, Collins L, Levin J. Pulsed dye laser repurposed: treatment of refractory molluscum contagiosum in renal transplant patient. Transpl Infect Dis. 2019;21(2): e13036. doi:10.1111/tid.2019.21.issue-2

65. Moye V, Cathcart S, Burkhart CN, Morrell DS. Beetle juice: a guide for the use of cantharidin in the treatment of molluscum contagiosum. Dermatol Ther. 2013;26(6):445-451. doi:10.1111/dth.12105

66. Ting PT, Dytoc MT. Therapy of external anogenital warts and molluscum contagiosum: a literature review. Dermatol Ther. 2004;17(1):68-101.

67. Vakharia PP, Chopra R, Silverberg NB, Silverberg JI. Efficacy and safety of topical cantharidin treatment for molluscum contagiosum and warts: a systematic review. Am J Clin Dermatol. 2018;19 (6):791-803. doi:10.1007/s40257-018-0375-4

68. Rush J, Dinulos JG. Childhood skin and soft tissue infections: new discoveries and guidelines regarding the management of bacterial soft tissue infections, molluscum contagiosum, and warts. Curr Opin Pediatr. 2016;28(2):250-257. doi:10.1097/MOP.0000000 000000334

69. Can B, Topaloglu F, Kavala M, Turkoglu Z, Zindanci I, Sudogan S. Treatment of pediatric molluscum contagiosum with $10 \%$ potassium hydroxide solution. $J$ Dermatolog Treat. 2014;25(3):246-248. doi:10.3109/09546634.2012.697988

70. Teixido C, Diez O, Marsal JR, et al. Efficacy and safety of topical application of $15 \%$ and $10 \%$ potassium hydroxide for the treatment of Molluscum contagiosum. Pediatr Dermatol. 2018;35(3):336-342. doi:10.1111/pde. 13438

71. Metkar A, Pande S, Khopkar U. An open, nonrandomized, comparative study of imiquimod $5 \%$ cream versus $10 \%$ potassium hydroxide solution in the treatment of molluscum contagiosum. Indian J Dermatol Venereol Leprol. 2008;74(6):614-618.

72. Skinner RB Jr. Treatment of molluscum contagiosum with imiquimod 5\% cream. J Am Acad Dermatol. 2002;47(4 Suppl):S221-S224.

73. Katz KA, Williams HC, van der Wouden JC. Imiquimod cream for molluscum contagiosum: neither safe nor effective. Pediatr Dermatol. 2018;35(2):282-283. doi:10.1111/pde.13398

74. Bohm M, Luger TA, Bonsmann G. Disseminated giant molluscum contagiosum in a patient with idiopathic CD4+ lymphocytopenia successful eradication with systemic interferon. Dermatology. 2008;217(3):196-198. doi:10.1159/000141649

75. Kilic SS, Kilicbay F. Interferon-alpha treatment of molluscum contagiosum in a patient with hyperimmunoglobulin E syndrome. Pediatrics. 2006;117(6):e1253-e1255. doi:10.1542/peds.2005-2706

76. Nelson MR, Chard S, Barton SE. Intralesional interferon for the treatment of recalcitrant molluscum contagiosum in HIV antibody positive individuals-a preliminary report. Int J STD AIDS. 1995;6 (5):351-352. doi:10.1177/095646249500600509

77. Enns LL, Evans MS. Intralesional immunotherapy with Candida antigen for the treatment of molluscum contagiosum in children. Pediatr Dermatol. 2011;28(3):254-258. doi:10.1111/j.1525-1470.2011.01492.x 
78. Chularojanamontri L, Tuchinda P, Kulthanan K, Manuskiatti W. Generalized molluscum contagiosum in an HIV patient treated with diphencyprone. J Dermatol Case Rep. 2010;4(4):60-62. doi:10.3315/ jdcr.2010.1059

79. Kang SH, Lee D, Hoon Park J, Cho SH, Lee SS, Park SW. Treatment of molluscum contagiosum with topical diphencyprone therapy. Acta Derm Venereol. 2005;85(6):529-530. doi:10.1080/ 00015550510034948

80. Erickson C, Driscoll M, Gaspari A. Efficacy of intravenous cidofovir in the treatment of giant molluscum contagiosum in a patient with human immunodeficiency virus. Arch Dermatol. 2011;147 (6):652-654. doi:10.1001/archdermatol.2011.20

81. Foissac M, Goehringer F, Ranaivo IM, et al. [Efficacy and safety of intravenous cidofovir in the treatment of giant molluscum contagiosum in an immunosuppressed patient]. Ann Dermatol Venereol. 2014;141(10):620-622. doi:10.1016/j.annder.2014.04.114

82. Toro JR, Wood LV, Patel NK, Turner ML. Topical cidofovir: a novel treatment for recalcitrant molluscum contagiosum in children infected with human immunodeficiency virus 1. Arch Dermatol. 2000;136 (8):983-985.

83. Vora SB, Brothers AW, Englund JA. Renal toxicity in pediatric patients receiving cidofovir for the treatment of adenovirus infection. J Pediatric Infect Dis Soc. 2017;6(4):399-402. doi:10.1093/jpids/pix011

84. Padilla Espana L, Mota-Burgos A, Martinez-Amo JL, BenaventeOrtiz F, Rodriguez-Bujaldon A, Hernandez-Montoya C. Recalcitrant molluscum contagiosum successfully treated with sinecatechins. Dermatol Ther. 2016;29(4):217-218. doi:10.1111/dth.12338
85. Viswanath V, Shah RJ, Gada JL. Intralesional 5-fluorouracil: novel therapy for extensive molluscum contagiosum in an immunocompetent adult. Indian J Dermatol Venereol Leprol. 2017;83(2):265-266. doi:10.4103/0378-6323.193626

86. Gao YL, Gao XH, Qi RQ, et al. Clinical evaluation of local hyperthermia at 44 degrees $\mathrm{C}$ for molluscum contagiosum: pilot study with 21 patients. $B r \quad J$ Dermatol. 2017;176(3):809-812. doi:10.1111/bjd.14849

87. Maiolo C, Marshman G. Zoster immunoglobulin-VF: a potential treatment for molluscum contagiosum in immunosuppressed children. Pediatr Dermatol. 2015;32(4):e193. doi:10.1111/ pde.2015.32.issue-4

88. Leung AKBB. Nasal verrucae vulgaris: an uncommon finding. Scholars J Med Case Rep. 2015;11:1036-1037.

89. Leung AK, Kao CP, Sauve RS. Scarring resulting from chickenpox. Pediatr Dermatol. 2001;18(5):378-380.

90. Stamm AW, Kobashi KC, Stefanovic KB. Urologic dermatology: a review. Curr Urol Rep. 2017;18(8):62. doi:10.1007/s11934-017-0712-9

91. Mizuashi M, Tamabuchi T, Tagami H, Aiba S. Focal presence of molluscum contagiosum in basal cell carcinoma. Eur J Dermatol. 2012;22(3):424-425. doi:10.1684/ejd.2012.1699

92. Hon KLLA. Acne: Causes, Treatment and Myths. New York: Nova Science Publishers, Inc.; 2010:1-89.

93. Paolino G, Muscardin LM, Panetta C, Donati M, Donati P. Linear ectopic sebaceous hyperplasia of the penis: the last memory of Tyson's glands. G Ital Dermatol Venereol. 2018;153(3):429-431. doi:10.23736/S0392-0488.16.05129-4

\section{Publish your work in this journal}

Clinical, Cosmetic and Investigational Dermatology is an international, peer-reviewed, open access, online journal that focuses on the latest clinical and experimental research in all aspects of skin disease and cosmetic interventions. This journal is indexed on CAS.
The manuscript management system is completely online and includes a very quick and fair peer-review system, which is all easy to use. Visit http://www.dovepress.com/testimonials.php to read real quotes from published authors. 